\title{
УСЛОВИЯ ПОВЫШЕНИЯ ЭФФЕКТИВНОСТИ ПСИХОЛОГО-ПЕДАГОГИЧЕСКОГО СОПРОВОЖДЕНИЯ ВОЕННО-ПРОФЕССИОНАЛЬНОЙ ПОДГОТОВКИ ИНОСТРАННЫХ СПЕЦИАЛИСТОВ (ПО ИТОГАМ КОНТРОЛЬНОГО ЭТАПА)
}

\section{CONDITIONS FOR IMPROVING THE EFFECTIVENESS OF PSYCHOLOGICAL AND PEDAGOGICAL SUPPORT FOR MILITARY PROFESSIONAL TRAINING OF FOREIGN SPECIALISTS (BASED ON THE RESULTS OF THE CONTROL STAGE) \\ L. Matyuschenko}

Summary: The article substantiates the relevance of the problem of improving the quality of psychological and pedagogical support for professional training of foreign military specialists in the Russian University, which is due, on the one hand, to the growing trend of demand for educational services by foreign specialists of military universities of the Russian Federation, due, among other things, to the active development of military and political cooperation between countries. And on the other hand - the lack of a multi-aspect scientific justification of the resource of psychological and pedagogical support of foreign specialists in a military University as an important factor in improving the quality of their professional training. This is also reflected in a number of state-level documents (resolution of the Government of the Russian Federation «on the provision by the Ministry of defence of the Russian Federation of services for the training and training of military and military-technical personnel of foreign States» No. 1164 of October 29,2015 , etc.).

In this regard, the research conducted on the basis of the Far Eastern higher military command order of Zhukov school named after Marshal of the Soviet Union K.K. Rokossovsky was based on system-activity, personality-oriented and cultural approaches, as well as scientific and methodological principles of accounting and understanding of Russian and foreign theoretical and practical experience of military pedagogy; compliance of directions, forms and methods of psychological and pedagogical support with the specifics of the military University, goalsetting, socio-cultural attitudes and motivation of trained foreign specialists, etc.

The experimental work identified and described the conditions of increase of efficiency of psychological and pedagogical support of foreign military experts, the students identified popular areas of activities of the teaching staff (psychology and pedagogical support of adaptation to new social, cultural and linguistic environment; tutoring; psychological and pedagogical assistance to formation of professionally important qualities and competencies, values on constructive current and planned interaction.

Keywords: military University, foreign specialists, educational process, military professional training, psychological and pedagogical support.
Матющенко Любовь Георгиевна, аспирант, Амурский государственный университет, г. Благовещенск (Россия) lubovm050@gmail.com

Аннотация: В статье обосновывается актуальность проблемы повышения качества психолого-педагогического сопровождения профессиональной подготовки иностранных военных специалистов в российском вузе, которая обусловлена, с одной стороны, тенденцией роста востребованности иностранными специалистами образовательных услуг военных вузов Российской Федерации, обусловленной, в том числе активным развитием военного и политического сотрудничества стран. И с другой стороны - недостаточностью полиаспектного научного обоснования ресурса психолого-педагогического сопровождения иностранных специалистов в военном вузе как важнейшего фактора повышения качества их профессиональной подготовки. Это нашло отражение и в ряде документов государственного уровня (Постановление Правительства Российской Федерации «0б оказании Министерством обороны Российской Федерации услуг по подготовке и обучению военных и военно-технических кадров иностранных государств» №1164 от 29 октября 2015 г. и др.).

Проведённое в этой связи на базе Дальневосточного высшего общевойскового командного ордена Жукова училища имени Маршала Советского Союза К.К. Рокоссовского исследование опиралось на системно-деятельностный, личностно-ориентированный и культурологический подходы, а также научно-методические принципы учёта и осмысления российского и зарубежного теоретико-практического опыта военной педагогики; соответствия направлений, форм и методов психолого-педагогического сопровождения специфике военного вуза, целеполаганию, социокультурным установкам и мотивации обучающихся иностранных специалистов и др.

В результате экспериментальной работы выявлены и описаны условия повышения эффективности психолого-педагогического сопровождения иностранных военных специалистов, определены востребованные обучающимися направления деятельности педагогического коллектива (психолого-педагогическая поддержка адаптации к новой социальной, культурной и языковой среде; тьюторство; психолого-педагогическое содействие формированию профессионально-важных качеств и компетенций, ценностных установок на конструктивное текущее и планируемое взаимодействие.

Ключевые слова: военный вуз, иностранные специалисты, образовательный процесс, военно-профессиональная подготовка, психолого-педагогическое сопровождение. 


\section{Введение}

$\mathrm{O}$ беспечение высокого качества военного профессионального образования и расширение спектра образовательных услуг являются одними из основных направлений модернизации современного образования в России $[1,3,9,11]$. При этом повышение престижа Российской Федерации в мире, признание её выдающихся технологических достижений в области современного вооружения обусловливают желание иностранных военных специалистов получить в нашей стране военно-профессиональное образование, имеющее свои характерные черты и признаки $[4,8,12]$. По мнению ряда учёных-исследователей, на современном этапе военно- профессиональное образование в Российской Федерации должно соответствовать требованиям:

1. качества военно-профессиональной составляющей, то есть таким военно-профессиональными знаниями, умениями и навыками, которые обеспечивают успешную деятельность будущего офицера в ситуациях глобально-политических вызовов времени;

2. развития технико-инновационной составляющей, что обусловливает необходимость владения специалистом приёмами грамотной эксплуатации боевой техники, эффективного её применения, навыками обеспечения постоянной боевой готовности и т.п. [5,6].

Для поступивших в российские военные вузы иностранных специалистов, которые закономерно испытывают определённые затруднения при адаптации в новой для них социально-культурной обстановке, в преодолении языкового барьера и т.п., это создаёт дополнительные трудности в понимании военной теории, при отработке необходимых умений и навыков, овладении специальной терминологией, понимании ценностного смысла российских военных традиций и ритуалов. Всё это актуализирует в научно-педагогическом дискурсе проблему определения оптимальных средств и условий повышения эффективности психолого-педагогического сопровождения военно-профессиональной подготовки иностранных специалистов $[7,10,14,15]$.

\section{Методология}

С целью решения исследовательской задачи выявления условий повышения эффективности психологопедагогического сопровождения военно-профессиональной подготовки иностранных специалистов на базе Дальневосточного высшего общевойскового командного ордена Жукова училища имени Маршала Советского Союза К.К. Рокоссовского был проведён развёрнутый педагогический эксперимент, в котором приняли участие 110 иностранных военных специалистов (далее - ИВС), 30 педагогов и сотрудников вуза.
Эксперимент проводился в течение трёх лет; в его основу было положено выявленное, обоснованное и описанное автором понимание психолого-педагогического сопровождения ИВС как целенаправленной системы деятельности всего педагогического коллектива военной образовательной организации, реализуемой в направлениях:

1. психолого-педагогической поддержки адаптации к новой социальной, культурной и языковой среде;

2. педагогического стимулирования потребностей иностранных военных специалистов в самообразовании, развитии личностной успешности;

3. психолого-педагогического содействия формированию профессионально-важных качеств, военно-профессиональных компетенций, развитию ценностных установок в рамках конструктивного межкультурного взаимодействия.

Основным условием реализации первого направления было признано обеспечение системной педагогической помощи (при необходимости - и педагогической коррекции) в понимании специфики образовательного процесса в российском военном вузе; в осознании социально-культурных и правовых норм поведения в вузе, в социуме; в обеспечении языковой подготовки, максимального «погружения» в среду речевой коммуникации.

Второе направление было соотнесено автором с реализацией такого педагогического условия, как целенаправленное содействие развитию у ИВС мета-учебных и специальных компетенций (понимание учебной задачи; планирование своих действий в соответствии с поставленной задачей и условиями её реализации; поиск и анализ информации, её классификация, выделение смысловых частей и причинно-следственных связей; преобразование информации в соответствии с учебной задачей и др.). В целях реализации данного условия уделялось внимание повышению информативной ёмкости и практической направленности содержания обучения; использованию интерактивных форм и приёмов, разработке учебных алгоритмов, образцов действий (в том числе, и с использованием виртуальных тренажёров, ИКT).

Важнейшим условием реализации третьего направления автором было признано максимальное вовлечение ИВС в совместные социокультурные мероприятия (соревнования «Лыжня России» и «Российский Азимут», фотокосплей, конкурс иллюстраций к литературным произведениям писателей стран Европы, Азии, Африки, участие в мастер-классе «Керамика» на базе ГПОАУ AO «Амурский педагогический колледж» и др.), а также в учебно-исследовательские и творческие проекты, за основу которых брались рекомендации по организации проектной деятельности на основе компетентностного подхода [2,13]. Всё это способствует более тесному учеб- 
но-исследовательскому и культурному сотрудничеству ИВС и российских курсантов, а также, что считаем важным, реализации дальнейшего позитивного диалога и сотрудничества между странами.

\section{Результаты исследования}

Проведённый в 2019 году контрольный этап педагогического эксперимента подтвердил обоснованность предположений об эффективности выявленных условий повышения качества психолого-педагогического сопровождения ИВС. На основе онлайн-опросов, комплексного анкетирования, анализа выполнения обучающимися учебных заданий, решения проблемно-учебных ситуаций, с помощью целенаправленного педагогического наблюдения за действиями и высказываниями обучающихся во время аудиторной и внеаудиторной деятельности, постоянной педагогической рефлексии, индивидуальных и групповых собеседований и др. было установлено следующее:

1. Целенаправленное психолого-педагогическое сопровождение ИВС с соблюдением отмеченных условий его реализации предопределило в ответах выпускников признание доступности и большой практической значимости изучаемых материалов, высокого уровня профессионализма преподавателей; около 90 \% респондентов высказали суждение о том, что полученная ими подготовка соответствовала их ожиданиям.

2. По сравнению с первоначальной диагностикой значительно увеличилось количество ответов респондентов, свидетельствующих о понимании ими учебной информации (таблица 1).

При этом отмечены определённые затруднения при усвоении теоретического материала по дисциплинам: «Эксплуатация бронетанкового вооружения и военной техники», «Электрооборудование и автоматика боевых машин», «Философия» и др.

Таблица 1.

Сравнение ответов респондентов на вопрос «Существует ли проблема с пониманием Вами учебной информации?»

\begin{tabular}{|l|l|l|}
\hline Вариант ответа & $\begin{array}{l}\text { Процент выбора ре- } \\
\text { спондентами в ходе } \\
\text { первоначальной диа- } \\
\text { гностики }\end{array}$ & $\begin{array}{l}\text { Процент выбора ре- } \\
\text { итоговой диагностики }\end{array}$ \\
\hline Никогда & $6,3 \%$ & $29,7 \%$ \\
\hline Редко & $32,5 \%$ & $26,3 \%$ \\
\hline Иногда & $44,6 \%$ & $56,4 \%$ \\
\hline Часто & $3,4 \%$ & $0,8 \%$ \\
\hline Всегда & $4,9 \%$ & $0 \%$ \\
\hline Нет ответа & $8,3 \%$ & $0,6 \%$ \\
\hline
\end{tabular}

3. У респондентов, иностранных специалистов, будущих выпускников, был отмечен оптимальный (67\%) уровень сформированности мета-компентенций, универсальных учебных действий. Об этом свидетельствует выполнение ИВС ряда заданий, связанных с анализом профессиональных кейс-ситуаций (к примеру, кейс по дисциплине «Теория управления»: «Вы назначены начальником полевого лагеря для проведения туристического 2-х недельного слета в количестве 60 участников. Используя сочетание системного и комплексного подхода, определите штатную структуру, порядок организации и проведения слета, функциональные обязанности должностных лиц и вопросы всестороннего обеспечения мероприятия используя указанную схему»).

4. По мнению респондентов, престижность и качество военно-профессиональной подготовки в российском вузе мотивируют их на поэтапное достижение карьерного роста с целью возможного утверждения на руководящей должности (отметили 73\% респондентов). В связи с этим у ИВС возросли требования к введению дополнительных знаний и развитию управленческих компетенций (доля запросов увеличилась с 8,6 \% до 24\%); к развитию правовых и информационноаналитических компетенций (рост с 17,4\% до 24,2 \%). Практически все респонденты отметили также значение полученных ими знаний о культуре и истории России, её конфессиях, национальной представленности, об особенностях поведения в общественных местах, гендерных отношениях. Более $60 \%$ респондентов приняли активное участие в разработке или реализации (подключились позже) проектов культурной направленности (создание виртуальных выставок, музеев, виртуально-обзорные путешествия по городам России т.п.).

Кроме этого, по результатам контрольного этапа экспериментальной деятельности автором отмечено значительное повышение уровня мотивации педагогов, сотрудников вуза к реализации таких функций психолого-педагогического сопровождения, как психодиагностическая, адаптивная, воспитательная, коммуникативная, организаторская и т.п.; а также их нацеленность на профессиональное развитие, обмен опытом, методическое обеспечение образовательного процесса, использованию активных форм обучения и т.п. Это также в рамках решения поставленных в исследовании задач отнесено к основополагающим условиям повышения качества психолого-педагогического сопровождения ИВС в российском вузе. 


\section{Зак^ючение}

Проведённый эксперимент подтвердил обоснованность предположений автора об эффективности выявленных направлений и условий повышения качества психолого-педагогического сопровождения ИВС. Ход и результаты экспериментальной работы позволили также определить наиболее оптимальные принципы их реализации. К таким принципам отнесены: обеспечение единства педагогического воздействия на личность, поддержки и содействия её развитию, стимулирования к самовоспитанию и саморазвитию; принцип поэтапного включения ИВС в систему военных ритуалов и традиций военного вуза, совместную деятельность в рамках его образовательных, воспитательных и общественных структур; принцип обеспечения развития инновационных подходов к образовательной деятельности с учётом ситуации опережающего обновления военной техники и современных тенденций оценки соответствующих компетенций.

На основе анализа итогов экспериментальной деятельности были также определены перспективы дальнейшего совершенствования качества психолого-педагогического сопровождения ИВС, к которым автором отнесены: развитие направлений и форм методической помощи преподавателям, в том числе на основе издания методических рекомендаций, проведения мастер-классов; расширение для ИВС спектра образовательных услуг дополнительного образования и возможностей подготовки как специалистов высшей квалификации.

\section{ЛИТЕРАТУРА}

1. Абрамов А.П. 06 эффективности военного образования // Социологические исследования. — 2015. — № 6 (374). — C.140-144

2. Беспалова В.В., Муравьева Г.Е. Разработка технологии проектирования образовательного процесса в вузе на основе компетентностного подхода // Преподаватель 21 века, -2011.- №2. - С.16-19

3. Гожиков В.Я. Организационно-педагогические основы модернизации гуманитарной подготовки курсантов военных вузов: дис... доктора педагогических наук. - Москва,2013. - 442 с.

4. Голик Н.М. Военное образование в модернизирующемся российском обществе// Вестник ВГУ. — 2013 — № 1 —. 140-145

5. Дудулин В.В., Столяревский С.П. Некоторые проблемы военно-профессиональной подготовки офицерских кадров // Мир образования - образование в мире. $-2017 .-$ № 1 (65). - С. 157-160

6. Евгеньев Д.Н., Столяров А.Л., Заец О.Г. Проблемы реализации педагогического мониторинга качества военно-профессиональной подготовки специалистов в военных вузах//Мир образования - образование в мире. -2017. - № 3 (67). - С. 264-270

7. Клепацкая И.Н. Роль компетентностного подхода в профессионально ориентированной подготовке по иностранному языку военных специалистов // Новая наука: от идеи к результату: Межд. научное периодич. издание по итогам Межд. научно—практич. конф. (22 октября 2016, г. Сургут); редкол. Р. Г. Юсупов [и др.]: в 3 ч. - Ч.2 — Стерлитамак: АМИ, 2016. - С. 66-68

8. Куршев А.В. Детерминанты и основные направления модернизации военного образования// Управление устойчивым развитием-2019. —№ 2 (21) - C. $95-99$

9. Михайловский В.Г., Дробот И.С., Рогожкин А.В. Нерастраченный потенциал системы военного образования // Alma mater. - 2015. - №4. - С.67-71

10. Павлушкина Т.В. Педагогическое сопровождение социальной адаптации иностранных военнослужащих в российском военном вузе: дис. . . кандидата педагогических наук. - Благовещенск - 2015.-191 с.

11. Разгонов В.Л., Суслов Д.В., Лопуха Т.Л. Теоретико-методологические основания смены парадигм военного образования // Мир науки, культуры, образования. -2018 . - № 1 (68). - С 91-97

12. Самедова Ю.А. Воспитание духовно-нравственных ценностей в военно-профессиональной подготовке будущих офицеров//Научные исследования и образование. -2018. - № 2 (30). - С. 7-10

13. Сафонова К.И., Подольский С.В. Проектная деятельность студентов в вузе: планирование проектов и оценка результативности их реализации//0бщество: социология, психология, педагогика. -2018. - №5. - С. 83-94

14. Смирнова А.Н. Трудности подготовки иностранных курсантов к обучению в российском военном вузе и пути их преодоления //Ярославский педагогический вестник. - 2014 — № 4 - Том II.-C.84-88.

15. Чухлебова И.А. Дидактическая система многоуровневой речевой подготовки иностранных военнослужащих в вузах Министерства Обороны Российской Федерации: автореф. дис... доктора педагогических наук. — Москва,2019.— 40 с.

() Матющенко Любовь Георгиевна (lubovm050@gmail.com).

Журнал «Современная наука: актуальные проблемы теории и практики» 